\title{
Kajian Yuridis Perlindungan Hak Tenaga Kerja Indonesia (TKI) di Luar Negeri
}

\author{
Aprina Chintya \\ Institut Agama Islam Negeri Metro \\ E-mail: aprinachintya64gmail.com
}

\begin{abstract}
Protection of employees is part inseparable from the protection of citizens as an obligation of the state. Nevertheless, the government still provides totally protection to the workers who work abroad, especially those who suffered torture and violence. This study aims to look at the study of the juridical protection of the rights of Indonesian Workers (TKI) abroad. This is a qualitative descriptive research. Data collection techniques in this study was documentation. After the data were obtained, the data were then analyzed by content analysis. The results showed that the presence of several laws such as the Law No. 39 Year 1999 on Human Rights and Law No. 39 of 2004 on the Protection and Placement of Indonesian Migrant Workers and their derivatives rules is the juridical basis of Indonesian workers who work abroad already provide legal protection for Indonesian workers abroad.
\end{abstract}

Keywords: Rights, Indonesian workers, Judicial, Regulatory, Protection.

\begin{abstract}
Abstrak
Perlindungan terhadap buruh/pekerja merupakan bagian yang tidak dapat terpisahkan dari perlindungan terhadap warga negara sebagai kewajiban negara. Meskipun demikian, pemerintah masih belum memberikan perlindungan yang maksimal kepada para TKI yang bekerja di luar negeri, khususnya mereka yang mengalami penyiksaan dan kekerasan. Penelitian ini bertujuan melihat kajian yuridis perlindungan hak Tenaga Kerja Indonesia
\end{abstract}


(TKI) di luar negeri. Penelitian ini adalah penelitian pustaka yang bersifat deskriptif kualitatif. Pengumpulan data dalam penelitian ini melalui dokumentasi. Sedangkan, teknik analisis data yang digunakan adalah konten analisis. Hasil penelitian menujukkan bahwa keberadaan beberapa peraturan perundangan seperti Undang-Undang No. 39 Tahun 1999 tentang HAM dan Undang-Undang No. 39 Tahun 2004 Tentang Perlindungan dan Penempatan Tenaga Kerja Indonesia beserta aturan-aturan turunannya merupakan landasan yuridis tenaga kerja Indonesia yang bekerja di luar negeri sudah memberikan payung hukum bagi tenaga kerja Indonesia di luar negeri.

Kata Kunci: Hak, TKI, Yuridis, Peraturan, Perlindungan.

\section{A. Pendahuluan}

\section{Latar Belakang}

Indonesia terus berupaya melakukan pembangunan nasional dalam rangka pembangunan manusia Indonesia seutuhnya guna mewujudkan masyarakat yang sejatera, adil dan makmur yang merata baik materil maupun spiritual berdasarkan pancasila dan Undang-Undang Dasar Negara republik Indonesia Tahun 1945. Di dalam pembangunan nasional, tenaga kerja memiliki peranan dan kedudukan yang sangat penting sebagai subyek pembangunan.

Perlindungan terhadap buruh/pekerja merupakan bagian yang tidak dapat terpisahkan dari perlindungan terhadap warga negara sebagai kewajiban negara. Hak-hak dasar sebagai manusia harus terpenuhi dengan mendapatkan perlindungan dimana saaja mereka berkerja untuk mendapatkan hak-hak dasarnya. Baik berbeda status warga negaranya maupun sama status werga negaranya, sehingga mereka mendapatkan kehidupan yang layak sebagai sesorang manusia sesuai dengan Pasal 28 D Ayat 3 UUD NRI 1945, bahwa: "Setiap warga negara memiliki Hak untuk bekerja 
dan mendapat imbalan serta perlakuan yang adil dan layak dalam hubungan kerja.",

Maraknya kasus penganiayaan kepada Tenaga Kerja Indonesia (selanjutnya disingkat TKI) yang bekerja di luar negeri, menyisakan pilu bagi keluarga, kerabat dan sanak saudaranya. Oleh sebab itu, tenaga kerja membutuhkan perlindungan hukum dan hak asasi manusia yang merupakan hak dasar yang melekat dan dilindungi oleh konstitusi sebagaimana yang diatur dalam pasal 27 ayat (2) UndangUndang dasar negara republik Indonesia tahun 1945 yang berbunyi " Tiap-tiap warga negara berhak atas pekerjaan dan penghidupan yang layak bagi kemanusiaan", dan Pasal 33 ayat (1) yang menyatakan bahwa" Pereknomian disusun sebagai usaha bersama atas kekeluargaan." Maka dari itu, pelanggaran terhadap hak dasar yang dilindungi oleh konstitusi merupakan pelanggaran hak asasi manusia.

Perlindungan terhadap tenaga kerja dimaksudkan untuk menjamin hak-hak dasar pekerja dan menjamin kesamaan kesempatan serta perlakuan tanpa diskriminasi atas apapun untuk mewujudkan kesejahteraan pekerja dan keluarganya dengan tetap memperhatikan perkembangan kemajuan dunia usaha dan kepentingan pengusaha. Peraturan perundangundangan yang terkait dengan perlindungan bagi pekerja yakni Undang-Undang no 13 Tahun 2003 tentang ketenaga kerjaan dan peraturan pelaksana dari perundang-undangan dibidang ketenagakerjaan.

Pelanggaran Hak Asasi Manusia (selanjutnya disingkat HAM) terhadap TKI selama ini berupa tidak dibayarnya gaji dan penganiayaan fisik. Pelanggaran ini adalah masalah yang cukup kompleks karena dalam hal ini melibatkan masalah diplomasi antar negara. Di satu sisi, Indonesia berupaya

${ }^{1}$ Fatkhul Muin, Perlindungan Hukum Terhadap Tenaga Kerja Indonesia (Tinjauan Terhadap Uu Nomor 39 Tahun 2004 Tentang Penempatan Dan Perlindungan Tenaga Kerja Indonesia), Jurnal Cita Hukum. Vol. II No. 1 Juni 2015, hlm. 12. 
menjaga hubungan baik diplomatik antar negara, dan di sisi lain hal ini menciptakan ketidakadilan dan duka mendalam bahkan merupakan penghinaan bagi TKI.

Dalam pasal 27 Ayat (2) UUD Negara Republik Indonesia Tahun 1945 disebutkan bahwa: Setiap warga negara berhak atas pekerjaan dan penghidupan yang layak bagi kemanusiaan. Dari amanat pembukaan UUD Negara Republik Indonesia Tahun 1945 dapat kita pahami bahwa tujuan pembangunan ketenagakerjaan adalah menciptakan lapangan pekerjaan bagi warga negara untuk mendapatkan penghidupan yang layak. ${ }^{2}$

Dalam Undang-Undang Nomor 13 Tahun 2003 tentang ketenagakerjaan telah mengatur perlindungan terhadap hakhak pekerja antara lain:

a. Hak atas upah yang layak.

b. Hak perlindungan atas keselamatan dan kesehatan kerja, termasuk hak istirahat dan cuti.

c. Hak atas PHK.

d. Hak untuk mogok kerja dan sebagainya.

Demikian juga Undang-Undang Nomor 39 tahun 2004 tentang penempatan Tenaga Kerja Indonesia di luar negeri. Dalam pasal 8 disebutkan bahwa setiap TKI memiliki hak dan kesempatan yang sama untuk:

a. Bekerja di luar negeri

b. Memperoleh informasi yang benar mengenai pasar kerja di luar negeri dan prosedur penempatan TKI di luar negeri

c. Memperoleh pelayanan dan perlakuan yang dama dan penempatan di luar negeri

d. Memperoleh kebebasan menganut agama dan keyakinan serta kesempatan untuk menjalankan ibadah sesuai dengan agama dan keyakinan yang dianutnya.

${ }^{2}$ Undang-Undang Dasar Negara Republik Indonesia 1945, Pasal 27 Ayat (2). 
e. Memperoleh upah sesuai dengan standar upah yang berlaku di negara tujuan

f. Memperoleh hak, kesempatan dan perlakuan yang sama yang diperoleh tenaga kerja asing lainnya sesuai dengan peraturan perundang-undangan di negara tujuan

g. Memperoleh jaminan perlindungan hukum sesuai dengan peraturan peundang-undangan atas tindakan yang dapat merendahkan harkat dan martabatnya serta pelanggaran atas hak-hak yang ditetapkan sesuai dengan peraturan perundnag-undangan selama penempatan di luar negeri

h. Memperoleh jaminan perlindungan keselamatan dan keamanan kepulangan TKI ke tempat asal

i. Memperoleh naskah perjanjian yang asli.

Berdasarkan ketentuan dalam undang-undang tersebut, jelas bahwa TKI memiliki jaminan hak yang jelas dan sangat rinci dalam melakukan kerja di luar negeri. Namun, pada kenyataannya banyak sekali hak-hak TKI yang dilanggar, baik oleh majikan maupun oleh PT penyalur TKI. Padahal, dalam hal ini TKI memiliki jaminan hak-haknya sebagai tenaga kerja.

Fenomena migrasi pekerja Indonesia ke luar negeri bukan hal yang luar biasa. Sejarah mencatat bahwa migrasi penduduk antar negara di kawasan Asia dan khususnya kawasan Asia Tenggara telah berlangsung berabad-abad. Saat ini angka migrasi pekerja Indonesia ke luar negeri setiap tahunnya mengalami peningkatan yang signifikan. ${ }^{3}$ Angka ini selalu meningkat dari tahun ke tahum. Meningkatnya angka pengiriman TKI ini membuat tanggung jawab pemerintah juga semakin besar.

${ }^{3}$ Mohamad Nico Diemoz Priatomo De May, Pelaksanaan Sistem Perlindungan Tenaga Kerja Indonesia Di Luar Negeri Yang Berasal Dari Jawa Timur Dalam Otonomi Daerah ( Studi Penanganan Kasus di Negara Tujuan Bekerja oleh Dinas Tenaga Kerja, Transmigrasi, dan Kependudukan Provinsi Jawa Timur), Jurnal UNIVERSITAS BRAWIJAYA, Malang, 2013, hlm. 2. 
Meskipun demikian dalam prakteknya, sampai sekarang pemerintah masih belum memberikan perlindungan yang maksimal kepada para TKI yang bekerja di luar negeri, khususnya mereka yang mengalami kekerasan. Peraturan perundang-undangan yang ada belum mampu menyelesaikan permasalahan TKI yang ada selama ini. Untuk itu, dalam penelitian ini, penting untuk melihat kajian yuridis perlindungan hak Tenaga Kerja Indonesia (TKI) di luar negeri.

\section{Rumusan Masalah}

Berdasarkankan latar belakang masalah tersebut, maka rumusan masalah dalam penelitian ini yaitu: bagaimana kajian yuridis perlindungan hak Tenaga Kerja Indonesia (TKI) di luar negeri?.

\section{B. Perlindungan Tenaga Kerja Indonesia (TKI) di Luar Negeri}

Manusia telah lahir dengan dilekati oleh hak-hak kodrat, hak-hak alamiah dan yang kemudian Ia sebut dengan hak-hak asasi. Selain dari konsep negara hukum yang berkembang di barat, di timur tengah pun berkembang konsep negara hukum dengan dasar negara madinah, dimana didasarkan kepada perjanjian yang dibuat oleh Nabi Muhammad SAW dengan penduduk madinah saat itu. Perjanjian tersebut menghasilkan konstitusi madinah sebagai undang-undang dasar negara madinah yang teruama mengatur kewajiban-kewajiban dan hak-hak warganegaranya. ${ }^{4}$

Pekerjaan adalah hal yang sangat penting dalam kehidupan manusia. Oleh sebab itu, setiap orang membutuhkan pekerjaan untuk mencukupi keberlangsungan hidupnya. Pekerjaan adalah sumber penghasilan seseorang untuk memenuhi kebutuhan hidup bagi dirinya dan

\footnotetext{
${ }^{4}$ Fatkhul Muin, Perlindungan Hukum., hlm. 18.
} 
keluarganya. Pekerjaan juga dapat dimaknai sebagai sarana untuk mengaktualisasikan diri sehingga seseorang merasa hidupnya menjadi lebih berharga baik bagi dirinya, keluarganya maupun lingkungannya. Oleh karena itu hak atas pekerjaan merupakan hak azasi manusia yang melekat pada diri seseorang yang wajib dijunjung tinggi dan dihormati. ${ }^{5}$

Dalam setiap pekerjaan, maka adanya perjanjian yang dibuat oleh para pihak, dimana perjanjian tersebut merupakan suatu peristiwa dimana pihak yang satu berjanji kepada pihak yang lainnya untuk melakukan suatu hal, akibatnya pihakpihak yang bersangkutan terikat oleh isi perjanjian yang mereka adakan. Sedangkan perjanjian kerja merupakan perjanjian yang dibuat antara buruh dengan majikan, dimana buruh menyatakan kesanggupannya untuk bekerja kepada majikan dengan menerima upah. ${ }^{6}$

Pada dasarnya, pemerintah telah mengambil langkahlangkah dalam melindungi TKI supaya mereka terhindar dari tindakan-tindakan yang merugikan mereka. Langkah-langkah tersebut antara lain:

a. Mengeluarkan Surat Keputusan Menakertrans Nomor 157/MEN/2003 tentang asuransi Perlindungan TKI di luar negeri

b. Menandatangani perjanjian kerjasama penempatan TKI (MOU) dengan beberapa negara penerima TKI yaitu Yordania serta Kuwait (1996) dan Malaysia (2004)

c. Melakukan pendampingan para TKI dibeberapa negara (Arab Saudi, Kuwait, dan Malaysia) oleh tim advokasi, yang beranggotakan PNS dan mahasiswa yang bekerja di negara itu serta pengacara lokal dari negara setempat.

${ }^{5}$ Adharinalti, Perlindungan Tenaga Kerja Terhadap Tki Irregular di Luar Negeri, dalam Jurnal Rechtsvinding, Volume 1 Nomor 1, 2012, hlm. 157.

6 Penjelasan Undang-Undang No. 39 Tahun 2004 Tentang Penempatan dan Perlindungan TKI. 
Tim advokasi ini bertugas mendata, memantau dan membela TKI di luar negeri

d. Memberlakukan sistem satu pintu untuk pengiriman TKI ke Singapura melalui embarkasi Batam

e. Meningkatkan kualitas TKI yang akan ditempatkan keluar negeri, khususnya untuk pembantu rumah tangga (PRT) dibatasi minimal berpendidikan SLTP. Mereka diharapkan mempunyai kemampuan yang leebih baik dalam ketrampilan kerja, penguasaan bahasa negara tujuan dan mempunyai kesiapan mental yang lebih baik serta sudah memenuhi syarat usia minimum TKI

f. Melakukan koordinasi dengan instansi terkait di negara penerima TKI dalam penanganan penempatan dan perlindungan TKI.

g. Mengeluarkan Undang-Undang Penempatan dan Perlindungan TKI di Luar Negeri (PPTKLN)

h. Mengeluarkan Undang-Undang Nomor 39 tahun 2004 tentang Penempatan dan Perlindungan Tenaga Kerja Indonesia di Luar negeri, dan terakhir,

i. Membentuk Badan Nasional Penempatan dan Perlindungan TKI (BPN2TKI) melalui Perpres No. 81 Tahun 2006. Lembaga ini merupakan lembaga pemerintah non departemen (LPND) yang mempunyai fungsi pelaksanaan kebijakan di bidang penempatan dan perlindungan TKI secara terkoordinir dan terintegrasi. Tugas badan ini yaitu memberikan pelayanan, mengkoordinasikan dan melakukan pengawasan, dokumen, pembekalan akhir pemberangkatan (PAP), penyelesaian masalah, sumber-sumber pembiayaan, pemberangkatan sampai pemulangan, peningkatan kualitas TKI. Bahkan juga mengurus perjanjian hukum secara tertulis antara Pemerintah RI dan pemerintah 
negara pengguna TKI atau pengguna berbadan hukum di negara yang dijadikan tujuan penempatan. ${ }^{7}$

Meskipun Pemerintah RI telah berupaya untuk melindungi tenaga kerja Indonesia di luar negeri, namun upaya tersebut pada kenyataannya masih memberikan peluang cukup terbuka kepada mafia-mafia PJTKI maupun pemerintah untuk merugikan TKI mulai dari perekrutan, penampungan, penempatan kerja hingga pemulangan ke Tanah Air.

\section{Tumpang Tindih Kebijakan Pemerintah}

Perlindungan terhadap TKI pada dasarnya merupakan tanggung jawab pemerintah secara umum. Namun secara khusus penanganan ini pada awalnya di kelola oleh Kementrian Tenaga Kerja dan Transmigrasi bersama-sama dengan Kementrian Luar Negeri. Namun pada kenyataannya, karena banyaknya berbagai kebutuhan maka pemerintah berupaya membantu tugas perlindungan Tenga Kerja Indinesia di luar negeri berdasarkan Undang-Undang Nomor 39 tahun 2004 sehingga terbentuklah Badan Nasional Penempatan dan Perlindungan Tenaga Kerja Indonesia (BNP2TKI) yang di atur dalam Peraturan Presiden Republik Indonesia Nomor 81 Tahun 2006.

Berdasarkan hal tersebut, sedikitnya ada tiga lembaga Negara yang memiliki keterkaitan dan bersinggungan secara langsung terhadap perlindungan TKI di luar negeri yaitu Kemenlu, Kementrian Ketenagakerjaan dan Transmigrasi serta BNP2TKI. Tugas mengenai Tenaga Kerja Indonesia awalnya di bebankan kepada salah satu biro di Kementrian Ketenagakerjaan dan Transigrasi. Namun, sejak adanya

${ }^{7}$ Erwan Baharudin, Perlindungan Hukum Terhadap TKI di Luar Negeri Pra Pemberangkatan, Penempatan, dan Purna Penempatan, dalam Lex Jurnalica, Jakarta: Universitas Esa Unggul, Vol.4 No.3, Agustus 2007 hlm. 173-174. 
BNP2TKI maka Tugas kementrian Ketenagakerjaan menjadi berkurang dan tugas tersebut beralih sepenuhnya di bawah tanggung jawab kepada Badan Penempatan dan Perlindungan TKI.

Kehadiran BNP2TKI bukan berarti bahwa semua persoalan menyangkut penempatan dan perlindungan TKI dapat di selesaikan tanpa melibatkan stakeholder lainya. Artinya, ada stakeholder lainya seperti Kementrian Luar Negeri dan Kementrian Ketenagakerjaan juga sangat berperan dalam membantu masalah TKI Tenga Kerja dalam upaya perlindunganya.

\section{Kajian Yuridis Perlindungan Hak Tenaga Kerja Indonesia (TKI) di Luar Negeri}

Peraturan perundang-undangandimaksud dalam kaitannya dengan penempatan dan perlindungan TKI yang bekerja diluar negeri adalah:

1. Undang-Undang No. 39 Tahun 1999 tentang HAM

Manusia dianugerahi oleh Tuhan yangMaha Esa akal budi dan nurani yang mem- berikan kepadanya kemampuan untuk mem bedakan yang baik dan yang buruk yangakan membimbing dan mengarahkan sikap dan perilaku dalam menjalani kehidupannya.Dengan akal budi dan nuraninya itu, makamanusia memiliki kebebasan untuk memutuskan sendiri perilaku atau perbuatannya.

Di samping itu, untuk mengimbangi kebebasan tersebut manusia memiliki kemampuan untuk bertanggungjawab atas semua tindakan yang dilakukannya. Kebebasan dasar dan hak-hak dasar itulah yang disebut hak asasi manusia yang melekat pada manusia secara kodrati sebagai anugerah Tuhan Yang Maha Esa. Hak-hak ini tidak dapat diingkari. 
Pengingkaran terhadap hak tersebut berarti mengingkari martabat kemanusiaan. ${ }^{8}$

Hal ini juga didukung dengan berbagai ketentuan yang ada dalam peraturan perundang-undangan yang sudah ada. Oleh sebab itu, segala hak yang melekat di dalamnya harus dihargai karena itu merupakan bagian dari martabat manusia.

2. Undang-Undang Nomor 39 Tahun 2004 tentang Penempatan dan Perlindungan Tenaga Kerja Indonesia di

Luar Negeri

Pada bagian konsideran menimbang menyebutkan bahwa (1) bekerja merupakan hak asasi manusia yang wajib dijunjung tinggi,dihormati, dan dijamin penegakannya, (2) Tenaga Kerja Indonesia di luar negeri sering dijadikan obyek perdagangan manusia, ter-masuk perbudakan dan kerja paksa, korbankekerasan, kesewenang-wenangan, kejahatan atas harkat dan martabat manusia, serta perlakuan lain yang melanggar hak asasi manusia. ${ }^{9}$

Dari landasan filosofis dibentuknya Undang-Undang ini jelaslah bahwa pokok pangkalnya berpijak dari konsep bekerja sebagai hak asasi manusia (HAM) yang wa- jib dihormati dan dijamin penegakannya, sementara kondisi empiris menunjukkan keprihatinan bahwa tenaga kerja Indonesiayang bekerja di luar negeri sering dijadikan obyek perdagangan manusia, termasuk perbudakan dan kerja paksa, korban kekerasan, kesewenang-wenangan, kejahatan atas harkat dan martabat manusia, serta perlakuanlain yang melanggar hak asasi manusia. Namun kondisi kontradiktif tampak pada konsideran bagian mengingat hanya merujuk Pasal dalam UUD Negara Republik Indonesia Tahun 1945 dan Undang-Undang Nomor 13 Tahun 2003 tentang Ketenagakerjaan, tidak mencantumkan Undang-Undang Nomor 39 Tahun 1999 tentang Hak Asasi Manusia (HAM).

\footnotetext{
${ }^{8}$ Lalu Husni, Perlindungan Terhadap Tenaga Kerja Indonesia di Luar Negeri, Dalam Jurnal mimbar, Volume 23 Nomor 1, 2011, hlm. 160.

${ }^{9}$ Ibid.
} 
Selain itu sesuai dengan nama Undang-Undang ini tentang penempatan dan perlindungan TKI di luar negeri, maka jelaslah bahwa Undang-Undang ini memiliki dimensi internasional, hubungan kerjasama bilateral dan subjek hukum negara penerima TKI. Karena itu selayaknya mencantumkan pula pada konsideran bagian mengingat Undang-Undang Nomor 37 Tahun 1999 tentangHubungan Luar Negeri, Undang-Undang Nomor 24 tentang Perjanjian Internasional.

Substansi perlindungan dalam undang-undang ini sangat sedikit. Ini bisa dilihat dari 109 pasal yang ada, hanya 8 pasal saja yang mengatur mengenai perlindungan TKI. Dengan lebih menekankan pada aspek penempatan TKI, maka Undang-Undang ini lebih bernuansa bisnis dari pada aspek perlindungan. Penempatan TKI untuk bekerja di luar negeri dianggap sebagai solusi untuk memecahkan persoalan ketenagakerjaan disaat pemerintah tidak mampu menyediakan pekerjaan bagi warga negaranya. Di samping itu, penempatan TKI untuk bekerja di luar negeri juga akan menambah devisa negara.

Lahirnya Undang-Undang Nomor 39 Tahun 2004 nampaknya masih memerlukan amandemen, karena dalam undnag-undang tersebut TKI dijadikan sebagai komoditi ekspor yang menghasilkan devisa semata, bukan sebagai manusia dengan segala harkat dan martabatnya.

Keberadaan Undang-Undang ini belum menciptakan sistem yang berpihak kepada TKI. Negara tidak segera membenahi celah dari Undang-Undang tersebut, maka bangsa kita dapat dikategorikan sebagai pelanggar Deklarasi Umum HAM (1948), Konvensi Pencegahan Perdagangan Manusia dan Eksploitasi Pelacur (1949), Konvensi Menentang Penyiksaan dan Perlakuan atau Hukum lain yang Kejam, Tidak Manusiawi dan Merendahkan Martabat Manusia (1984), dan Konvensi Hak Anak (1989), karena Indonesia merupakan negara yang ikut menandatangani 
semua konvensi tersebut. bangsa kita dapat dikategorikan sebagai pelanggar Deklarasi Umum HAM (1948), Konvensi Pencegahan Perdagangan Manusia dan Eksploitasi Pelacur (1949), Konvensi Menentang Penyiksaan dan Perlakuan atau Hukum lain yang Kejam, Tidak Manusiawi dan Merendahkan Martabat Manusia (1984), dan Konvensi Hak Anak (1989), karena Indonesia merupakan negara yang ikut menandatangani semua konvensi tersebut.

Undang-Undang No. 32 Tahun 2004 tentang Pemerintahan Daerah Otonomi daerah yang diatur dengan Undang-Undang Nomor 22 tahun 1999 jo. 32 Tahun 2004 tentang Pemerintahan Daerah menganut prinsip otonomi seluas-luasnya dalam arti daerah diberikan kewenangan untuk mengatur dan mengurus semua urusan pemerintahan di luar urusan yangmerupakan kewenangan Pemerintah yakni politik luar negeri, pertahanan, keamanan,moneter, yustisi, dan agama. Daerah diberi-kan kewenangan membuat kebijakan dalam memberikan pelayanan, peningkatan peranserta, prakarsa, dan pemberdayaan masyarakat yang bertujuan untuk peningkatan kesejahteraan masyarakat.

Penyelenggaraan urusan pemerintahan dibagi berdasarkan kriteria eksternalitas, akuntabilitas, dan esiensi dengan memperhatikan keserasian hubungan antar susunan pemerintahan. Penyelenggaraan urus-an pemerintahan merupakan pelaksanaan hubungan kewenangan antara Pemerintah dan pemerintahan daerah provinsi, kabupaten dan kota atau antarpemerintahan daerahyang saling terkait, tergantung, dan sinergissebagai satu sistem pemerintahan. Urusan pemerintahan yang menjadi kewenangan pemerintahan daerah, terdiri atas urusanwajib dan urusan pilihan.

Urusan pemerintahan wajib adalah urusan pemerintahan yang wajib diselenggarakan oleh pemerin-tahan daerah yang terkait dengan pelayanan dasar (basic services) bagi masyarakat. Urusan pemerintahan yang bersifat pilihan 
adalah urusan pemerintahan yang diprioritaskan oleh pemerintahan daerah untuk diselenggarakan yang terkait dengan upaya mengembangkan potensi unggulan (corecom petence) yang menjadi kekhasan daerah. Khusus dalam bidang ketenagakerjaan yang merupakan fokus kajian ini, urusan wajib yang menjadi kewenangan pemerintahan daerah propinsi merupakan urusan dalamskala propinsi yang meliputi pelayanan bidang ketenagakerjaan lintas kabupaten/kota (Pasal 13 huruf h).

Urusan wajib yang menjadi kewenangan pemerintahan daerahuntuk kabupaten/kota merupakan urusanyang berskala kabupaten/kota yang meliputi pelayanan bidang ketenagakerjaan (Pasal 14huruf h). Penjabaran lebih lanjut mengenai pem- bagian urusan ini diatur dalam Peraturan Pemerintah Nomor 38 Tahun 2007 tentangPembagian Urusan Pemerintahan antara Pemerintah, Pemerintahan Daerah Provinsi,dan Pemerintahan Daerah Kabupaten/Kota.

Dalam pembagian urusan kewenangan yang diatur dalam Peraturan Pemerintah, tersebut, pemerintah daerah (Propinsi maupun Kabupaten/Kota) tidak diberika nkewenangan dalam bidang perlindungan calon TKI. Pemerintah berpandangan bahwa perlindungan TKI merupakan kewenangan pemerintah karena berkaitan dengan negara lain, padahal perlindungan bagi TKI tidak saja pada saat penempatan, tetapi mulai dari daerah asal (prapenempatan) yangmeliputi pemberian informasi pasar kerjaluar negeri dan prosedur penempatan TKI diluar negeri, serta pelayanan dan perlakuanyang sama dalam penempatan di luar negeri(Pasal 8 huruf b, c UndangUndang Nomor 39 Tahun 2004 tentang Penempatan dan Perlindungan TKI di Luar Negeri). Ironisnya pemerintah melimpahkan kewenangannya itu kepada Pelaksana Penempatan TKI Swasta (PPTKIS). 


\section{E. Kesimpulan}

Berdasarkan uraian di atas, maka dapat disimpulkan bahwa keberadaan beberapa peraturan perundangan seperti Undang-Undang No. 39 Tahun 1999 tentang HAM dan Undang-Undang No. 39 Tahun 2004 Tentang Perlindungan dan Penempatan Tenaga Kerja Indonesia beserta aturanaturan turunannya merupakan landasan yuridis tenaga kerja Indonesia yang bekerja di luar negeri sudah memberikan payung hukum bagi tenaga kerja Indonesia di luar negeri. Meskipun demikian, ada beberapa substansi dari UndangUndang ini yang belum menciptakan sistem yang berpihak kepada TKI. Oleh sebab itu, kedepannya diharapkan akan adanya amandemen dari kedua undang-undang tersebut.

\section{Daftar Pustaka}

Adharinalti, Perlindungan Tenaga Kerja Terhadap Tki Irregular di Luar Negeri, dalam Jurnal Rechtsvinding, Volume 1 Nomor 1, 2012.

Erwan Baharudin, Perlindungan Hukum Terhadap TKI di

Luar Negeri Pra Pemberangkatan, Penempatan, dan Purna Penempatan, dalam Lex Jurnalica, Jakarta: Universitas Esa Unggul, Vol.4 No.3, Agustus 2007.

Fatkhul Muin, Perlindungan Hukum Terhadap Tenaga Kerja Indonesia (Tinjauan Terhadap Uu Nomor 39 Tahun 2004 Tentang Penempatan Dan Perlindungan Tenaga Kerja Indonesia), Jurnal Cita Hukum. Vol. II No. 1 Juni 2015.

Lalu Husni, Perlindungan Terhadap Tenaga Kerja Indonesia di Luar Negeri, Dalam Jurnal mimbar, Volume 23 Nomor 1, 2011.

Mohamad Nico Diemoz Priatomo De May, Pelaksanaan Sistem Perlindungan Tenaga Kerja Indonesia Di Luar 
Negeri Yang Berasal Dari Jawa Timur Dalam Otonomi Daerah ( Studi Penanganan Kasus di Negara Tujuan Bekerja oleh Dinas Tenaga Kerja, Transmigrasi, dan Kependudukan Provinsi Jawa Timur), Jurnal UNIVERSITAS BRAWIJAYA, Malang, 2013. 